\title{
Tingkat Kepuasan Konsumen Terhadap Kualitas Pelayanan Minimarket
}

\author{
Ety Sufiyanti ${ }^{1 *}$, A. Jalaludin Sayutu ${ }^{2}$ dan Ayu Oka Windarti ${ }^{3}$ \\ ${ }^{1}$ Jurusan Administrasi, Politeknik Negeri Sriwijaya, Indonesia \\ ${ }^{2}$ Jurusan Administrasi, Politeknik Negeri Sriwijaya, Indonesia \\ ${ }^{3}$ Jurusan Administrasi, Politeknik Negeri Sriwijaya, Indonesia
}

\begin{abstract}
:
This study determine the level of customer satisfaction towards service quality at Minimarket Mutiara Indah Palembang, with purpose to determine how percentage level of customer satisfaction, and also to determine what kind of service quality dimension which had dominant. Collected data had used quesioner with the respondent 60 people, and the technique of collected sample used Non Probability Sampling with Accidental Sampling method. Based on the result known that average percentage from every dimension were tangible dimension was $65,1 \%$, reability dimension was $74 \%$, responsiveness dimension was $79,8 \%$, assurance dimension was 74,2 \% and empathy dimension was 75,6\%. So, dimension which has dominant at Minimarket Mutiara Indah Palembang was responsiveness dimension with 79,8\% to the fast of employee to find product which customer want to bought.
\end{abstract}

Keywords: level of satisfaction, service quality

\section{PENDAHULUAN}

Perkembangan dan persaingan dalam dunia bisnis kian hari semakin ketat, ini merupakan salah satu dampak dari era globalisasi saat ini. Sebagai contoh contohnya terlihat pada perkembangan bisnis ritel seperti minimarket. Oleh karena itu masing-masing dari minimarket ini bersaing bagaimana caranya agar dapat meningkatkan kepuasan konsumennya. Untuk dapat bersaing, pihak manajemen dari perusahaan ritel harus melakukan strategi bersaing untuk dapat memenangkan persaingan. Salah satu caranya yaitu dengan memperhatikan kualitas pelayanan.

Menurut Garvin dan Davis dalam Nasution (2004:41) kualitas adalah suatu kondisi dinamis yang berhubungan dengan produk, manusia/tenaga kerja, proses, dan tugas, serta lingkungan yang memenuhi atau melebihi harapan pelanggan atau konsumen.

*Email korespondensi:

Ety Sufiyanti

etysofianti7@gmail.com
Sedangkan Kotler dalam Nasution (2004:104), menyatakan bahwa kepuasan konsumen adalah tingkat perasaan seseorang setelah membandingkan kinerja atau hasil yang ia rasakan dibandingkan dengan harapannya.

Kepuasan konsumen sangat berpengaruh terhadap kemajuan perusahaan. Karena jika kepuasan konsumen tidak diperhatikan maka, konsekuensi yang akan diterima yaitu kosumen akan berpindah ke minimarket yang lain, dan juga ketidakpuasan konsumen tersebut dapat mempengaruhi calon konsumen yang lain, sehingga dapat menyebabkan perusahaan tidak dapat bertahan apabila tidak diperhatikan pelayanannya. Sebaliknya jika kepuasan konsumen diperhatikan dan konsumen merasa puas maka, akan membuat konsumen untuk tetap menjalin hubungan dengan perusahaan, dengan kata lain konsumen akan menjadi pelanggan setia dan tetap berbelanja di minimarket tersebut.

Berdasarkan uraian mengenai permasalahan diatas tadi, penulis ingin lebih 
mengetahui seberapa besar tingkat kepuasan melalui dimensi-dimensi kualitas pelayanan menurut Parasuraman et.al dalam Lupiyoadi (2011:148) yaitu berupa dimensi bukti fisik (tangible), keandalan (reability), ketanggapan (responsiveness), jaminan (assurance), dan dimensi perhatian (empathy), itu merupakan dimensi yang akan dianalisis lebih lanjut ke dalam penelitian ini. Dapat kita ketahui bahwa kualitas pelayanan mempunyai peranan yang sangat penting bagi perusahaan dalam menciptakan kepuasan konsumen. Pada penelitian ini peneliti ingin mengetahui tingkat kepuasan konsumen terhadap kualitas pelayanan pada Minimarket Mutiara Indah Palembang. Permasalahan yang dapat dirumuskan pada penelitian ini adalah: seberapa besar tingkat kepuasan konsumen terhadap kualitas pelayanan pada Minimarket Mutiara Indah. Dimensi kualitas pelayanan manakah yang paling dominan terhadap kepuasan konsumen pada Minimarket Mutiara Indah.

\section{TINJAUAN PUSTAKA}

Secara umum pemasaran dapat didefinisikan sebagai salah satu kegiatan pokok yang perlu dilakukan oleh perusahaan baik itu perusahaan yang bergerak dalam bidang manufaktur ataupun perusahaan yang bergerak dalam bidang jasa untuk mempertahankan kelangsungan hidup usahanya. Salah satu aspek yang penting dilakukan untuk menjaga kelangsungan hidup usaha adalah menjaga kulitas pelayanan terhadap konsumen agar mereka puas, karena memberikan kepuasan terhadap konsumen dapat melingkupi pelayanan tepat waktu, akurat, dan memuaskan.

Menurut Kotler dalam Lupiyoadi (2013:7), mendefinisikan bahwa "Jasa adalah setiap tindakan atau kegiatan yang dapat ditawarkan oleh satu pihak kepada pihak lain, pada dasarnya tidak berwujud dan tidak mengakibatkan perpindahan kepemilikan apa pun, produksi jasa mungkin berkaitan dengan produk fisik atau tidak".

Sedangkan pengertian jasa Menurut Lovelock dalam Wijaya (2012:5) ada 3 yaitu: a. Tindakan atau perbuatan yang ditawarkan satu kelompok kepada kelompok lain.

b. Aktivitas ekonomi yang menciptakan nilai serta menyediakan manfaat bagi pelanggan pada waktu dan tempat tertentu.

c. Suatu yang dapat dibeli dan dijual.

Berdasarkan definisi diatas maka dapat disimpulkan bahwa pada dasarnya jasa merupakan suatu aktivitas atau kegiatan ekonomi yang tidak berwujud yang diberikan kepada konsumen untuk memenuhi kebutuhannya.

Menurut Griffin dalam Lupiyoadi (2011:6) mengatakan bahwa ada tiga karakteristik jasa, diantaranya adalah sebagai berikut:

1. Intangibility (Tidak Berwujud)

Jasa tidak dapat dilihat, dirasa, diraba, didengar, atau dicium sebelum jasa itu dibeli. Nilai penting dari hal ini adalah nilai tak berwujud yang dialami konsumen dalam bentuk kenikmatan, kepuasan, atau rasa aman.

2. Unstorability (Tidak Dapat Disimpan) Jasa tidak mengenal persediaan atau penyimmpanan dari produk yang telah dihasilkan. Karakteristik ini disebut juga inseparability (tidak dapat dipisahkan) mengingat pada umumnya jasa dihasilkan dan dikonsumsi secara bersamaan.

3. Customization (Kustomisasi)

Jasa sering kali didesain khusus untuk kebutuhan pelanggan, misalnya pada jasa asuransi dari kesehatan.

\section{Kualitas Pelayanan}

Menurut Garvin dan Davis dalam Nasution (2004:41) kualitas adalah suatu kondisi dinamis yang berhubungan dengan produk, manusia/tenaga kerja, proses, dan tugas, serta lingkungan yang memenuhi atau melebihi harapan pelanggan atau konsumen. Lebih lanjut Feigenbaum dalam Nasution (2004:41), menyatakan bahwa kualitas adalah kepuasan konsumen sepenuhnya (full 
customer satisfaction). Suatu produk berkualitas apabila dapat memberi kepuasan sepenuhnya kepada konsumen, yaitu sesuai dengan apa yang diharapkan konsumen atas suatu produk.

Menurut Kotler (2002:83) pelayanan adalah setiap tindakan atau kegiatan yang dapat ditawarkan oleh suatu pihak kepada pihak lain, yang pada dasarnya tidak berwujud dan tidak mengakibatkan kepemilikan apapun.

Berdasarkan definisi diatas, kualitas pelayanan adalah kegiatan yang berhubungan dengan produk, manusia/tenaga kerja, proses, dan tugas, serta lingkungan, yang pada dasarnya tidak berwujud dan tidak mengakibatkan kepemilikan apapun.

\section{Dimensi Kualitas Pelayanan}

Dimensi Kualitas Pelayanan Menurut Parasuraman et.al dalam Lupiyoadi (2011:148) ada 5 (lima) dimensi, yaitu:

1. Berwujud (tangible), yaitu kemampuan suatu perusahaan dalam menunjukkan eksistensinya kepada pihak eksternal. Penampilan dan kemampuan sarana dan prasarana fisik perusahaan yang dapat diandalkan keadaan lingkungan sekitarnya merupakan bukti nyata dari pelayanan yang diberikan oleh pemberi jasa, meliputi fasilitas fisik (gedung, gudang, dan lain sebagainya), perlengkapan dan peralatan yang dipergunakan (teknologi), serta penampilan pegawainya.

2. Keandalan (reability) yaitu kemampuan perusahaan untuk memberikan pelayanan sesuai yang dijanjikan secara akurat dan terpercaya. Kinerja harus sesuai dengan harapan pelanggan yang berarti ketepatan waktu, pelayanan yang sama untuk semua pelanggan tanpa kesalahan, sifat yang simpatik, dan dengan akurasi yang tinggi.

3. Ketanggapan (responsiveness) yaitu suatu kebijakan untuk membantu dan memberikan pelayanan yang cepat (responsif) dan tepat kepada pelanggan, dengan peyampaian informasi yang jelas.
Membiarkan konsumen menunggu tanpa ada alasan yang jelas menyebabkan persepsi negatif dalam kualitas pelayanan.

4. Jaminan (assurance) yaitu pengetahuan, kesopan santunan, dan kemampuan para pegawai perusahaan untuk menumbuhkan rasa percaya para pelanggan kepada perusahaan. Hal ini meliputi beberapa komponen antara lain komunikasi (communication), kredibilitas (credibility), keamanan (security), kompetensi (competence), dan sopan santun (courtesy).

5. Perhatian (empathy) yaitu memberikan perhatian yang tulus dan bersifat individual atau pribadi yang diberikan kepada para pelanggan dengan berupaya memahami keinginan konsumen. Dimana suatu perusahaan diharapkan memiliki pengertian dan pengetahuan tentang pelanggan, memahami kebutuhan pelanggan secara spesifik, serta memiliki waktu pengoperasian yang nyaman bagi pelanggan.

\section{Kepuasan Konsumen}

Menurut Abdullah dan Tantri (2012:38), kepuasan adalah tingkat perasaan seseorang setelah membandingkan kenerja produk (atau hasil) yang ia rasakan dengan harapannya. Tingkat kepuasan merupakan fungsi dari perbedaan antara kinerja yang dirasakan dan harapan. Jika kinerja dibawah harapan pelanggan akan tidak puas. Kalau kinerja sesuai dengan harapan, pelanggan akan puas. Apabila kinerja sesuai dengan harapan, pelanggan akan sangat puas, senang atau bahagia.

Engel dalam Nasution(2004:104), mengungkapkan bahwa kepuasan pelanggan merupakan evaluasi pembeli, di mana alternatif yang dipilih sekurang-kurangnya memberikan hasil (outcome) sama atau melampaui harapan pelanggan, sedangkan ketidakpuasan timbul apabila hasil diperoleh tidak memenuhi harapan pelanggan.

Sedangkan Kotler dalam Nasution (2004:104), menyatakan bahwa kepuasan 
konsumen adalah tingkat perasaan seseorang setelah membandingkan kinerja atau hasil yang ia rasakan dibandingkan dengan harapannya.

Setiap konsumen berusaha untuk memenuhi kebutuhan hidupnya dengan pemenuhan yang maksimal. Jumlah dan keanekaragaman barang yang dapat dipenuhi bergantung pada besar pendapatan / penghasilan.

\section{Pengukuran Kepuasan Konsumen}

Ada empat alat untuk melacak dan mengukur kepuasan konsumen menurut Kotler dalam (Tjiptono 2002;148), alat-alat tersebut adalah:

1. Sistem keluhan dan saran

Perusahaan dapat menyediakan formulir yang berisi keluhan dan saran yan dapat diisi di setiap pintu masuk, meja penerima tamu dan lain-lain. Formulir tersebut diisi konsumen dengan keluhan dan saran mereka sehingga perusahaan dapat mengetahui kesulitan-kesulitan yang dihadapi oleh konsumen terhadap pelayanan perusahaan dan dapat mengambil tindakan untuk mengatasi masalahnya dan hal yang disarankan oleh konsumen sebagai pemecahan masalah yang dihadapi konsumen.

2. Survei kepuasan konsumen

Melalui survei, perusahaan akan memperoleh tanggapan dan umpan balik secara langsung dari pelanggan dan juga memberikan tanda positif bahwa perusahaan menaruh perhatian terhadap para pelanggannya. Pengukuran kepuasan melalui metode ini menurut Kotler, dapat dilakukan dengan beberapa cara, yaitu:
a. Directly Reported Satisfaction
b. Derived Dissatisfaction
c. Problem Analysis
d. Importance-performance Analysis

3. Belanja Siluman (Ghost Shopping)

Metode ini dilaksanakan dengan cara mempekerjakan beberapa orang (ghost shopper) untuk berperan dan bersikap sebagai pelanggan atau pembeli potensial produk perusahaan pesaing. Lalu ghost shopper tersebut menyampaikan temuannya mengenai kekuatan dan kelemahan produk dari perusahaan pesaing berdasarkan pengalaman mereka dalam pembelian produk-produk tersebut. Selain itu para ghost shopper juga dapat mengamati dan menilai cara perusahaan dan pesaingnya menjawab pertanyaan pelanggan dan menangani setiap keluhan.

4. Analisis kehilangan pelanggan

Metode ini sedikit unik, perusahaan berusaha menghubungi para pelanggannya yang telah berhenti membeli atau yang beralih pemasok. Yang diharapkan adalah akan diperolehnya informasi penyebab terjadinya hal tersebut. Informasi ini sangat bermanfaat dalam rangka meningkatkan kepuasan dan loyalitas konsumen.

\section{BAHAN DAN METODE}

Menurut Sugiyono (2008:115-116), pengertian populasi dan sampel adalah sebagai berikut: Populasi adalah wilayah generalisasi yang terdiri atas: obyek/subyek yang mempunyai kualitas dan karakteristik tertentu yang ditetapkan oleh peneliti untuk dipelajari dan kemudian ditarik kesimpulannya. Populasi dalam penelitian ini adalah konsumen yang berbelanja di Minimarket Mutiara Indah yang tidak diketahui jumlahnya karena Minimarket Mutiara Indah memiliki banyak konsumen.

Sampel adalah bagian dari jumlah karakteristik yang dimiliki oleh populasi tersebut. Bila populasi besar, dan peneliti tidak mungkin mempelajari semua yang ada pada populasi, misalnya karena keterbatasan dana, tenaga dan waktu, maka peneliti dapat menggunakan sampel yang diambil dari populasi itu. Apa yang dipelajari dari sampel itu, kesimpulannya akan dapat diberlakukan untuk populasi. Untuk itu sampel yang diambil dari populasi harus betul-betul mewakili. 
Dikarenakan jumlah populasi yang tidak diketahui pasti jumlahnya, maka untuk menentukan jumlah sampel yang akan digunakan sebagai responden dapat menggunakan metode penentuan sampel menurut (Sugiyono 2008:129), yang menyatakan untuk menentukan sampel yang tidak diketahui secara pasti jumlah populasinya, maka peneliti dapat menggunakan teori Roscoe, yaitu:

$$
n=(\mathrm{Vx}+\mathrm{Vy}) \mathrm{x} 10
$$

Keterangan:

$\mathrm{n}=$ Ukuran sampel

$\mathrm{Vx}=$ Jumlah variabel X (Dimensi kualitas pelayanan yaitu dimensi tangible, realibility, responsiveness, assurance, dan empathy)

$\mathrm{Vy}=$ Jumlah variabel Y (kepuasan konsumen)

Maka akan diperoleh hasil sebesar:

$$
\begin{aligned}
\mathrm{n} & =(\mathrm{Vx}+\mathrm{Vy}) \times 10 \\
& =(5+1) \times 10 \\
& =6 \mathrm{x} 1 \\
& =60 \text { sampel }
\end{aligned}
$$

Teknik yang dilakukan dalam pengambilan sampel adalah teknik nonprobability sampling, yaitu probabilita dari elemen tidak diketahui (Yusi dan Idris, 2009:67). Teknik pengambilan sampel yang digunakan yaitu dengan metode accidental sampling. Accidental Sampling adalah teknik penentuan sampel berdasarkan kebetulan, yaitu siapa saja yang secara kebetulan/insidental bertemu dengan peneliti dapat digunakan sebagai sampel, bila dipandang orang yang kebetulan ditemui cocok sebagai sumber data (Sugiyono, 209:122).

Adapun perhitungan persentase jawaban menggunakan rumus Riduwan (2008:18) berikut:

$$
\text { Persentase }=\frac{\text { Total skor } \times 100 \%}{\text { Skor Maksimal }}
$$

$$
\text { Skor Maks. }=\frac{\text { Skor Tertinggi }}{\text { Jumlah Responden }}
$$

Menurut Yusi dan Idris (2009:80 intrepretasi persentase ini dapat menggunakan kriteria pada Tabel 1.

\section{HASIL DAN PEMBAHASAN}

Untuk mengetahui identitas responden berdasarkan jenis kelamin, berikut adalah tabel identitas responden berdasarkan usia.

Tabel 1 Kriteria Interpretasi

\begin{tabular}{|l|l|l|}
\hline No & Skor/Angka & Interpretasi \\
\hline 1 & $0 \%-20 \%$ & Sangat Rendah \\
\hline 2 & $21 \%-40 \%$ & Rendah \\
\hline 3 & $41 \%-60 \%$ & Sedang \\
\hline 4 & $61 \%-80 \%$ & Tinggi \\
\hline 5 & $81 \%-100 \%$ & Sangat Tinggi \\
\hline
\end{tabular}

Tabel 2 Responden Berdasarkan Jenis Kelamin

\begin{tabular}{|c|l|c|c|}
\hline No & $\begin{array}{c}\text { Jenis } \\
\text { Kelamin }\end{array}$ & Jumlah & Persentase \\
\hline 1 & Laki-laki & 27 & $45 \%$ \\
\hline 2 & Perempuan & 33 & $55 \%$ \\
\hline \multicolumn{2}{|c|}{ Total } & 60 & $100 \%$ \\
\hline
\end{tabular}

Sumber: Data Diolah, 2016

Berdasarkan Tabel 2 diatas diketahui bahwa jenis kelamin responden laki-laki berjumlah 27 orang atau 45 persen, sedangkan yang berjenis kelamin perempuan yaitu sebanyak 33 orang atau 55 persen.

Untuk mengetahui identitas responden berdasarkan usia, berikut adalah tabel identitas responden berdasarkan usia.

Tabel 3 Responden Berdasarkan Usia

\begin{tabular}{|c|l|c|c|}
\hline No & Usia & Jumlah & Persentase \\
\hline 1 & $<20$ Tahun & 6 & $10 \%$ \\
\hline 2 & $21-35$ Tahun & 12 & $20 \%$ \\
\hline 3 & $36-45$ Tahun & 39 & $65 \%$ \\
\hline 4 & $>46$ Tahun & 3 & $5 \%$ \\
\hline \multicolumn{2}{|c|}{ Total } & 60 & $100 \%$ \\
\hline
\end{tabular}

Sumber: Data Diolah, 2016 
Berdasarkan Tabel 3 di atas dapat diketahui bahwa usia responden didominasi dari usia $<20$ tahun yaitu 6 orang responden atau sebesar 10 persen, sedangkan usia 21-35 tahun yaitu 12 orang atau sebesar 20 persen, usia 36-45 tahun yaitu 39 orang atau sebesar 65 persen dan yang terakhir usia $>46$ tahun sebanyak 3 orang atau sebesar 5 persen dari keseluruhan responden.

Untuk mengetahui identitas responden berdasarkan pekerjaan, berikut adalah tabel identitas responden berdasarkan pekerjaan.

Tabel 4 Responden Berdasarkan Pekerjaan

\begin{tabular}{|c|l|c|c|}
\hline No & \multicolumn{1}{|c|}{ Usia } & Jumlah & Persentase \\
\hline 1 & $\begin{array}{l}\text { Pegawai Negeri / } \\
\text { Swasta }\end{array}$ & 27 & $45 \%$ \\
\hline 2 & $\begin{array}{l}\text { Pelajar / } \\
\text { Mahasiswa }\end{array}$ & 9 & $15 \%$ \\
\hline 3 & $\begin{array}{l}\text { Pengusaha / } \\
\text { Wiraswasta }\end{array}$ & 18 & $30 \%$ \\
\hline 4 & Lain-lain & 6 & $10 \%$ \\
\hline \multicolumn{2}{|c|}{ Total } & 60 & $100 \%$ \\
\hline
\end{tabular}

Sumber: Data Diolah, 2016

Berdasarkan Tabel 4 dapat diketahui bahwa pekerjaan responden didominasikan pegawai negeri / swasta sebanyak 27 orang responden atau 45 persen, pelajar / mahasiswa sebanyak 9 orang responden atau 15 persen, pengusaha / wiraswasta sebanyak 18 orang responden atau 30 persen, dan yang terakhir lain-lain sebanyak 6 orang atau 10 persen.

Hasil pengukuran kepuasan konsumen secara keseluruhan dapat dilihat pada Tabel 5. Berdasarkan data yang diperoleh dari 60 responden, karyawan mempunyai pengetahuan terhadap kebutuhan dan keinginan konsumen. Data juga menunjukkan bahwa responden menyatakan ketanggapan karyawan dalam melayani keinginan konsumen tergolong tinggi.

Berdasarkan informasi dan rekapitulasi tanggapan responden dan hasil skala pengukuran kepuasan konsumen secara keseluruhan dapat dilihat pada Tabel 6 . Berdasarkan Tabel 6, diketahui bahwa dimensi bentuk fisik memilik persentase sebesar 65,1 persen contohnya seperti "tersedianya tempat parkir", dimensi keandalan sebesar 74 persen contohnya seperti "ketepatan dalam memecahkan masalah konsumen", dimensi ketanggapan sebesar 79,8 persen contohnya seperti "kecepatan karyawan dalam menemukan produk yang dicari", dimensi jaminan adalah sebesar 74,2 persen contohnya seperti" Produk yang dijual terjamin mutu dan kualitas serta keasliannya", dan terakhir dimensi perhatian yaitu sebesar 75,6 persen contohnya seperti "karyawan dapat berkomunikasi dengan baik dengan para konsumen". Jika ditampilkan dalam bentuk grafik, maka persentase pada setiap dimensi adalah sebagai berikut jika dilihat dari Gambar 1. Dari hasil ini dapat diketahui dimensi yang paling dominan yaitu pada dimensi ketanggapan (responsiveness) yaitu kecepatan karyawan dalam menemukan produk yang dicari konsumen yaitu mendapatkan 89 persen dan persentase ratarata sebesar 79,8 persen tingkat kepuasan dari konsumen Minimarket Mutiara Indah Palembang.

\section{KESIMPULAN DAN SARAN}

Berdasarkan hasil pengukuran dimensi kualitas pelayanan pada Minimarket Mutiara Indah Palembang diketahui bahwa persentase rata-rata dari dimensi keandalan (reability), dimensi ketanggapan (responsiveness), dimensi jaminan (assurance), dan dimensi perhatian (empathy) sudah diatas 70 persen. Dari hasil pengukuran dimensi kualitas pelayanan pada Minimarket Mutiara Indah Palembang, diketahui bahwa dimensi ketanggapan (responsiveness) memiliki persentase ratarata sebesar 79,8 persen seperti "kecepatan karyawan dalam menemukan produk yang dicari konsumen" yang berarti memilik persentase rata-rata yang paling tinggi dibandingkan dari empat dimensi lainnya, dan ini juga membuktikan bahwa dimensi ketanggapan merupakan dimensi yang paling dominan. 
Tabel 5 Rekapitulasi Jawaban dari Pertanyaan-pertanyaan pada Setiap Dimensi

\begin{tabular}{|c|c|c|c|c|c|c|c|}
\hline \multirow{2}{*}{ No } & \multirow{2}{*}{ Indikator } & \multicolumn{5}{|c|}{ Jumlah } & \multirow{2}{*}{ Total } \\
\hline & & TP & $\mathbf{K P}$ & $\mathbf{C P}$ & $\mathbf{P}$ & SP & \\
\hline \multicolumn{8}{|c|}{ Bukti Langsung (Tangible) } \\
\hline 1 & $\begin{array}{l}\text { Letak miniarket yang strategis sehingga } \\
\text { mudah dijangkau }\end{array}$ & 0 & 0 & 19 & 24 & 17 & 60 \\
\hline 2 & Tersedianya tempat parkir & 23 & 27 & 10 & 0 & 0 & 60 \\
\hline 3 & Karyawan berpenampilan dengan rapi & 0 & 15 & 18 & 21 & 6 & 60 \\
\hline 4 & $\begin{array}{l}\text { Produk yang dijual lengkap dan mudah } \\
\text { ditemukan }\end{array}$ & 0 & 1 & 18 & 23 & 18 & 60 \\
\hline \multicolumn{8}{|c|}{ Keandalan (Reability) } \\
\hline 1 & $\begin{array}{l}\text { Kecepatan dan ketelitian karyawan kasir } \\
\text { dalam melayani konsumen }\end{array}$ & 1 & 3 & 22 & 24 & 10 & 60 \\
\hline 2 & $\begin{array}{l}\text { Karyawan mempunyai kemampuan untuk } \\
\text { memerikan pelayanan yang baik kepada } \\
\text { semua konsumen }\end{array}$ & 2 & 4 & 20 & 23 & 11 & 60 \\
\hline 3 & $\begin{array}{l}\text { Ketepatan dalam memecahkan masalah } \\
\text { konsumen }\end{array}$ & 1 & 2 & 19 & 22 & 16 & 60 \\
\hline \multicolumn{8}{|c|}{ Ketanggapan (Responsiveness) } \\
\hline 1 & $\begin{array}{l}\text { Ketanggapan karyawan dalam mmelayani } \\
\text { keinginan konsumen }\end{array}$ & 0 & 0 & 20 & 24 & 16 & 60 \\
\hline 2 & $\begin{array}{l}\text { Pemberian informasi yang jelas oleh } \\
\text { karyawan minimarket }\end{array}$ & 0 & 0 & 19 & 29 & 12 & 60 \\
\hline 3 & $\begin{array}{l}\text { Kecepatan karyawan dalam menemukan } \\
\text { produk yang dicari konsumen }\end{array}$ & 0 & 0 & 3 & 27 & 30 & 60 \\
\hline 4 & $\begin{array}{l}\text { Kesediaan karyawan untuk mendengarkan } \\
\text { keluhan dari konsumen }\end{array}$ & 1 & 5 & 18 & 24 & 12 & 60 \\
\hline \multicolumn{8}{|c|}{$\begin{array}{cc}\text { Jaminan (Assurance) } \\
\end{array}$} \\
\hline 1 & $\begin{array}{l}\text { Keamanan konsumen yang terjamin selama } \\
\text { berbelanja di minimarket (adanya } \\
\text { security/petugas keamanan) }\end{array}$ & 3 & 3 & 26 & 28 & 0 & 60 \\
\hline 2 & $\begin{array}{l}\text { Tersedianya peralatan keamanan dan } \\
\text { keselamatan konsumen (CCTV, Alat } \\
\text { pemadam api, pintu darurat) }\end{array}$ & 0 & 3 & 18 & 21 & 18 & 60 \\
\hline 3 & $\begin{array}{l}\text { Produk yang dijual terjamin mutu dan } \\
\text { kualitas serta keasliannya }\end{array}$ & 0 & 0 & 13 & 35 & 12 & 60 \\
\hline 4 & $\begin{array}{l}\text { Karyawan berlaku ramah dan sopan santun } \\
\text { kepada konsumen }\end{array}$ & 0 & 1 & 24 & 26 & 9 & 60 \\
\hline \multicolumn{8}{|c|}{$\begin{array}{ll}\text { Perhatian (Empathy) } \\
\end{array}$} \\
\hline 1 & $\begin{array}{l}\text { Karyawan dapat berkomunikasi dengan baik } \\
\text { dengan para konsumen }\end{array}$ & 0 & 1 & 20 & 27 & 12 & 60 \\
\hline 2 & $\begin{array}{l}\text { Waktu operasional (jam buka) minimarket } \\
\text { yang nyaman dan aman bagi konsumen }\end{array}$ & 0 & 0 & 22 & 28 & 10 & 60 \\
\hline 3 & $\begin{array}{l}\text { Pemahaman karyawan akan keluhan } \\
\text { konsumen }\end{array}$ & 0 & 3 & 20 & 27 & 10 & 60 \\
\hline 4 & $\begin{array}{l}\text { Karyawan mempunyai pengetahuan terhadap } \\
\text { kebutuhan dan keinginan konsumen }\end{array}$ & 0 & 2 & 22 & 26 & 10 & 60 \\
\hline
\end{tabular}

Sumber: Data Diolah, 2016 
Tabel 6 Tabel Skala Pengukuran

\begin{tabular}{|c|c|c|c|c|c|}
\hline No & Indikator & Persentase & $\begin{array}{l}\text { Titik } \\
\text { Puas }\end{array}$ & Gol. & Rata-Rata \\
\hline \multicolumn{6}{|c|}{ Bukti Langsung (Tangibles) } \\
\hline 1 & $\begin{array}{l}\text { Letak miniarket yang strategis sehingga } \\
\text { mudah dijangkau }\end{array}$ & $79,3 \%$ & Puas & Tinggi & \multirow{4}{*}{$65,1 \%$} \\
\hline 2 & Tersedianya tempat parkir & $35,7 \%$ & $\begin{array}{c}\text { Kurang } \\
\text { Puas }\end{array}$ & Rendah & \\
\hline 3 & Karyawan berpenampilan dengan rapi & $66 \%$ & Puas & Tinggi & \\
\hline 4 & $\begin{array}{l}\text { Produk yang dijual lengkap dan mudah } \\
\text { ditemukan }\end{array}$ & $79,3 \%$ & Puas & Tinggi & \\
\hline \multicolumn{6}{|c|}{ Keandalan (Reability) } \\
\hline 1 & $\begin{array}{l}\text { Kecepatan dan ketelitian karyawan kasir } \\
\text { dalam melayani konsumen }\end{array}$ & $73 \%$ & Puas & Tinggi & \multirow[b]{3}{*}{$74 \%$} \\
\hline 2 & $\begin{array}{l}\text { Karyawan mempunyai kemampuan untuk } \\
\text { memberikan pelayanan yang baik kepada } \\
\text { semua konsumen }\end{array}$ & $72,3 \%$ & Puas & Tinggi & \\
\hline 3 & $\begin{array}{l}\text { Ketepatan dalam memecahkan masalah } \\
\text { konsumen }\end{array}$ & $76,7 \%$ & Puas & Tinggi & \\
\hline \multicolumn{6}{|c|}{ Ketanggapan (Responsiveness) } \\
\hline 1 & $\begin{array}{l}\text { Ketanggapan karyawan dalam melayani } \\
\text { keinginan konsumen }\end{array}$ & $78,7 \%$ & Puas & Tinggi & \multirow[b]{4}{*}{$\mathbf{7 9 , 8 \%}$} \\
\hline 2 & $\begin{array}{l}\text { Pemberian informasi yang jelas oleh } \\
\text { karyawan minimarket }\end{array}$ & $77,7 \%$ & Puas & Tinggi & \\
\hline 3 & $\begin{array}{l}\text { Kecepatan karyawan dalam menemukan } \\
\text { produk yang dicari konsumen }\end{array}$ & $89 \%$ & $\begin{array}{l}\text { Sangat } \\
\text { Puas }\end{array}$ & $\begin{array}{l}\text { Sangat } \\
\text { Tinggi }\end{array}$ & \\
\hline 4 & $\begin{array}{l}\text { Kesediaan karyawan untuk mendengarkan } \\
\text { keluhan dari konsumen }\end{array}$ & $73,7 \%$ & Puas & Tinggi & \\
\hline \multicolumn{6}{|c|}{$\begin{array}{l}\text { Jaminan (Assurance) } \\
\end{array}$} \\
\hline 1 & $\begin{array}{l}\text { Keamanan konsumen yang terjamin } \\
\text { selama berbelanja di minimarket (adanya } \\
\text { security/petugas keamanan) }\end{array}$ & $66,3 \%$ & Puas & Tinggi & \\
\hline 2 & $\begin{array}{l}\text { Tersedianya peralatan keamanan dan } \\
\text { keselamatan konsumen (CCTV, Alat } \\
\text { pemadam api, pintu darurat) }\end{array}$ & $78 \%$ & Puas & Tinggi & \\
\hline 3 & $\begin{array}{l}\text { Produk yang dijual terjamin mutu dan } \\
\text { kualitas serta keasliannya }\end{array}$ & $79,7 \%$ & Puas & Tinggi & $74,2 \%$ \\
\hline 4 & $\begin{array}{l}\text { Karyawan berlaku ramah dan sopan } \\
\text { santun kepada konsumen }\end{array}$ & $74,3 \%$ & Puas & Tinggi & \\
\hline \multicolumn{6}{|c|}{$\begin{array}{ll}\text { Perhatian (Empathy) } \\
\end{array}$} \\
\hline 1 & $\begin{array}{l}\text { Karyawan dapat berkomunikasi dengan } \\
\text { baik dengan para konsumen }\end{array}$ & $76,7 \%$ & Puas & Tinggi & \\
\hline 2 & $\begin{array}{l}\text { Waktu operasional (jam buka) minimarket } \\
\text { yang nyaman dan aman bagi konsumen }\end{array}$ & $76 \%$ & Puas & Tinggi & \\
\hline 3 & $\begin{array}{l}\text { Pemahaman karyawan akan keluhan } \\
\text { konsumen }\end{array}$ & $74,7 \%$ & Puas & Tinggi & \\
\hline 4 & $\begin{array}{l}\text { Karyawan mempunyai pengetahuan } \\
\text { terhadap kebutuhan dan keinginan } \\
\text { konsumen }\end{array}$ & $74,7 \%$ & Puas & Tinggi & $75,6 \%$ \\
\hline
\end{tabular}

Sumber: Data Diolah, 2016

Jurnal Riset Bisnis dan Investasi 


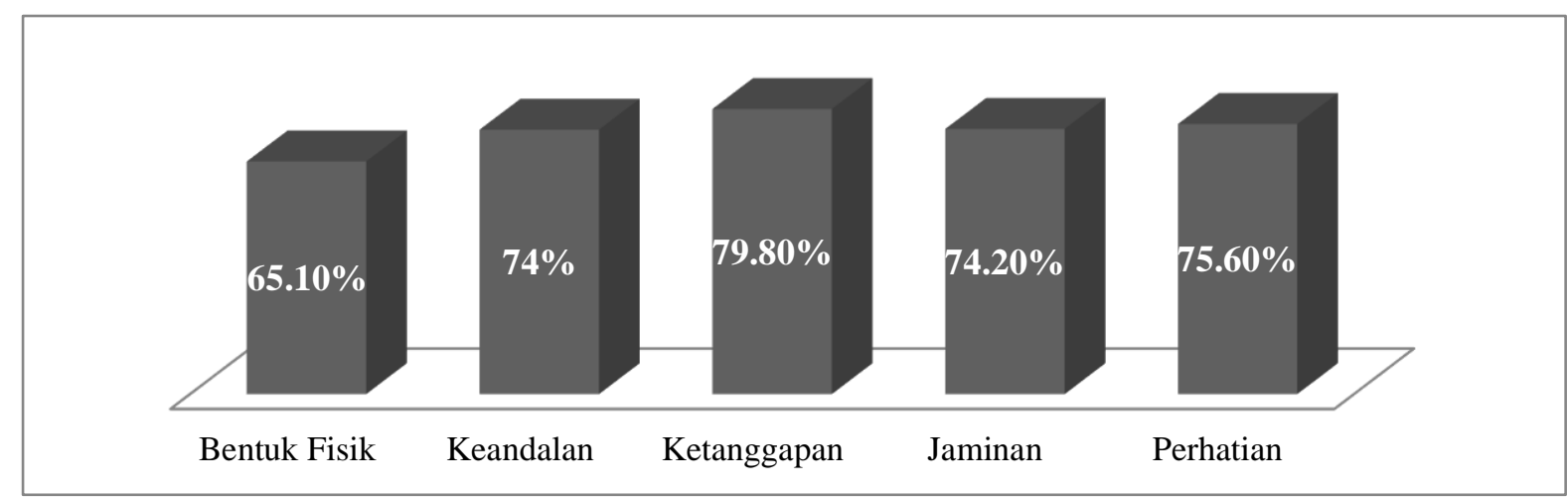

Gambar 1 Grafik Persentase Kepuasan Konsumen per Dimensi

Oleh karena persentase yang paling dominan adalah dimensi ketanggapan (responsiveness) atau "kecepatan karyawan dalam menemukan produk yang dicari konsumen" sebesar 79,8 persen, maka dari itu pihak perusahaan harus mempertahankan kualitas pelayanan pada dimensi tersebut.

\section{DAFTAR PUSTAKA}

Abdullah, T. \& Francis T. (2012). Manajemen Pemasaran. Jakarta: PT Rajagrafindo Persada

Daryanto. (2011). Manajemen Pemasaran. Bandung: PT Sarana Tutorial Nurani Sejahtera

Handoko, T. H. (2003). Manajemen. Cetakan Kedelapanbelas. Yogyakarta: BPFE

Hasibuan, M. S. P. (2007). Manajemen. Jakarta: PT Bumi Aksara

Kotler, P. (2002). Manajemen Pemasaran. Jakarta: PT Ikrar Mandiriabadi

Kotler, P. (2008). Manajemen Pemasaran. Jakarta: Prenhallindo
Lupiyoadi, R. (2011). Manajemen Pemasaran Jasa. Jakarta: Salemba Empat

Lupiyoadi, R. (2013). Manajemen Pemasaran Jasa. Jakarta: Salemba Empat

Nasution, M. N. (2004). Manajemen Jasa Terpadu. Jakarta: Ghalia Indonesia

Riduwan. (2008). Dasar-Dasar Statistika. Bandung: Alfabeta

Sugiyono. (2008). Metode Penelitian Kuantitatif Kualitatif $R \& D$. Bandung: Alfabeta

Swastha, B. \& Irawan. (2008). Manajemen Pemasaran Modern. Yogyakarta: Liberty.

Tjiptono, F. (2002). Manajemen Jasa. Yogyakarta: ANDI

Wijaya, D. (2012). Pemasaran Jasa Pendidikan. Jakarta: Salemba Empat

Yusi, S. \& Idris, U. (2009). Metodologi Penelitian Ilmu Sosial Pendekatan Kuantitatif. Palembang: CitraBooks Indonesia 